\title{
Language Changes in Late-Onset Alzheimer's Disease
}

\section{Мовні зміни в особистостей з хворобою Альцгеймера пізнього початку}

\author{
Eda Can \\ Еда Кан \\ Ph.D. in General Linguistics, \\ Lecturer \\ кандидат філологічних наук, \\ викладач \\ E-mail: eda.can@deu.edu.tr \\ orcid.org/0000-0002-0061-1843
}

Gülmira Kuruoğlu

Ph.D. in Linguistics, Professor

\section{Гульміра Куруоглу}

кандидат філологічних наук, професор

E-mail: gulmira.kuruoglu@deu.edu.tr
orcid.org/0000-0002-4172-0253

Dokuz Eylul University,

Faculty of Letters, Department of Linguistics

Buca-Izmir, Turkey, 35390
Університет Докуз Ейлул, факультет літератури, кафедра лінгвістики

$\triangle$ Буча-Ізмір, Турція, 35390

Original manuscript received September 12, 2018

Revised manuscript accepted February 25, 2019

\begin{abstract}
Alzheimer's disease (AD) is the most common cause of cognitive decline and dementia in the elderly. Language disturbances appear early in $A D$ and constitute an important element of the diagnosis, although they are usually overshadowed by impairment of memory and executive functions. It is known that language is impaired disproportionally in AD: the semantic and pragmatic language systems are more impaired than syntax. However, syntactic features can also be impaired in
\end{abstract}


the moderate and severe stages of $A D$. The features of language can be different depending on the onset of $A D$. $A D$ is classified into two subtypes: early-onset (before 65 years of age) and late-onset (over 65 years of age). Late-onset is the most common form of $A D$ and the aim of this study is to reveal the language changes of 39 patients with late-onset $A D$ and compare it with an age/education-matched control group that has no neurological and psychological problems. The data was transcribed using transcript symbols following Du Bois. The results revealed that although the number of the sentences were more, the speech amount of late-onset AD patients was smaller than the control group. Late-onset $A D$ patients mostly produced sentences in "Picnic» picture description test and fewer sentences in random speech test. Moreover, the sentence length of LAD patients was bigger in "Cookie theft» picture description test and smaller in "Picnic» picture description test. However, their general performance about the speech amount was poor. The other findings were about the coordinated and compound sentences. It was revealed that late-onset $A D$ patients used similar number of coordinated and compound sentences compared to their aged matched peers. In conclusion, it is clear that the syntactic features of LAD patients is not completely different from the people with normail aging.

Key words: Alzheimer, late-onset Alzheimer's Disease, coordinated sentences, compound sentences, sentence length.

\section{Introduction}

Alzheimer's disease (AD) is a progressive and fatal disease of the brain. It is degenerative disease of the brain that leads to a condition called dementia. Dementia is a general term used to describe the loss of memory and mental abilities severe enough to affect daily life (Lu \& Bludau, 2011).

$\mathrm{AD}$ is the most common type of dementia, comprising 60 to 80 percent of all dementias (Swartout-Corbei, 2001; Gourle, 2001; Atkins, 2008; Lu \& Bludau, 2011; Mandell \& Green, 2011). Because of this, the word dementia is sometimes used interchangeably, with AD (Lu \& Bludau, 2011). The course of the disease is progressive, with the onset insidious. Early deficits include recent memory, followed by problems in orientation, language, and abstract thinking (Soukup, 1996). Language disorders figure amongst the most significant symptoms of AD (Thomas \& Hazif-Thomas, 2015).

AD affects brain cells responsible for learning, reasoning, and memory (Franz, 2001). It is characterized by an insidious onset of progressive impairment of memory and other areas of cognition, 
including orientation, language, visuospatial function and praxis (Camicioli, 2007). Patients with AD progress through mild, moderate, and severe stages, and more than half are expected to be at the moderate or severe stages of the disease at any given time (Ferris \& Farlow, 2013). During the early stages, there is usually a recognition of lost capacities and abilities with expressed concern and anxiety. As the disorder progresses, problems develop in social and occupational areas. Individuals with $\mathrm{AD}$ fail to recognize familiar faces, develop problems with attention, concentration, and simple task completion (Soukup, 1996).

Typical effects of AD include declines in memory, executive capacity, and linguistic ability (Cummings, 2007). Language change can be a valuable biological marker of overall cognitive change in $\mathrm{AD}$ and other forms of dementia (Zimmerer et al., 2016). As cognitive abilities decline, language quality changes. Research has shown that well-constructed sentences filled with ample information and vivid descriptions fade to what is often known as «empty speech» (as cited in Sundermann, 2012).

Those with $\mathrm{AD}$ often have a number of linguistic deficits, including difficulties finding words, diminished vocabularies, a difficulty recalling the names of everyday objects (anomia), a tendency to speak with repetitions (echolalia), a difficulty producing sounds, syllables and words (verbal apraxia) (Masrani, 2018).

Speech and language pathologists and neurologists have known for about 100 years that certain areas in the left hemisphere of the brain - Broca's area in the posterior frontal lobe and Wernicke's area in the temporal lobe - are centrally involved in language functions. Damage to Broca's area results in problems with language fluency: shortened sentences, impaired flow of speech, poor control of rhythm and intonation (known as prosody); and a telegraphic style with missing inflections. In contrast, the speech of individuals with injury in Wernicke's area is fluent and often rapid, but with relatively empty content and many neologisms (invented words) and word substitutions (Davidson \& Villiers, 2011).

Language disorders can be understood as an impaired language system, involving word finding, word retrieval or anomia. It is the left hemisphere of the brain which is particularly connected with the language functions. There are two specific areas of the brain whose 
damage causes language impairments. Those are Broca's area in the posterior frontal lobe and Wernicke's area in the temporal lobe. Harm to Broca's area causes difficulties with language fluency, while harm to Wernicke's area affects the speech which is fluent, however, it lacks the content (Guha, 2012).

Progressive and isolated language dissolution occasionally is the dominant clinical manifestation of what proves pathologically to be $\mathrm{AD}$. In general, however, language impairment either parallels or follows that of memory, but language loss is not «global» until end stage; even then some patients who are otherwise mute retain minimal verbal responsiveness to their names or other audible stimuli (Mandell \& Green, 2011).

Language characteristics for a given patient depend upon the severity of the dementia and loss in most cases occurs in a predictable sequence. Both output (speech and writing) and input (auditory and reading comprehension) are affected. Early, some linguistic functions are clearly better preserved than others, but, again, adequate testing almost always shows preservation to be relative when compared to properly matched normals (Mandell \& Green, 2011).

Memory system disruptions are observed in AD patients: Episodic memory (early and severe impairment), Semantic memory (moderate impairment), Working memory (moderate impairment). Because the hippocampus and other medial temporal lobe structures are the earliest and most severely affected brain regions in $\mathrm{AD}$, episodic memory is the earliest and most impaired cognitive function. Common symptoms include asking the same questions repeatedly, repeating the same stories, forgetting appointments, and leaving the stove on. Patients with AD show anterograde amnesia or difficulty learning new information. They also show retrograde amnesia or difficulty retrieving previously learned information. Patients with semantic memory disruption exhibit deficits in naming, single-word comprehension, and impaired general knowledge (such as the color of common items). Because working memory depends upon networks which include frontal and parietal cortical regions as well as subcortical structures, most neurodegenerative diseases impair working memory. Because it involves the silent rehearsal of verbal information, almost any type of aphasia may impair phonologic working memory (Budson, 2011). Due to these memory disorders, 
language / speech features of $\mathrm{AD}$ patients can be different from people with normal aging.

Neuroimaging and lesion studies have long implicated inferior frontal lobe structures in grammatical processing. Grammatical deficits have been reported in both $\mathrm{AD}$ and the non-fluent variant of primary progressive aphasia (Reilly, Troche \& Grossman, 2011). The conclusion that grammar is spared in AD is also based on two kinds of evidence: (1) spontaneous correction of grammatical errors in sentence repetition; (2) spontaneous speech that contains a normal range of simple and complex phrase structure types, with no evidence of function word omissions and/or grammatical substitutions (as cited in Bates et al., 1995).

At the beginning, language deficits are not severe; however, these problems become severe during the later stages of AD (Emery, 2000). When phonological abilities are considered, it can be seen that these abilities are not affected severely during mild and moderate stages of AD (Bayles \& Kazniak, 1987; Glosser et al., 1998; Kemper et al., 1993). The dominant theoretical position is that phonological processing is well preserved until late stages of AD. Empirical support for this assumption has been derived from studies showing that speech production in $\mathrm{AD}$ is similar to healthy control participants on tasks such as reading orthographically regular words aloud, and producing connected speech (as sited in Reilly, Troche and Grossman, 2011).

Like phonological abilities, syntactic features of AD patients are often preserved in the early stages and become severely affected in the later stages (Bayles \& Kazniak, 1987; Glosser et al., 1998; Kemper et al., 1993). In fact, the effect of AD on syntax is controversial. Some researchers have reported syntactic impairments in $\mathrm{AD}$, while others claim that any apparent deficits are in fact due to difficulties with memory and semantics. Several studies have found evidence for a decrease in the syntactic complexity of language in AD (Fraser et al., 2016).

Some researchers have argued that genuine syntactic deficits are apparent in $\mathrm{AD}$. Others have hypothesized that many apparent syntactic defi cits reflect methodological artifact. For example, the integrity of grammar is often probed by asking patients to make acceptability judgments of sentence structures with some syntactic violation 
(e.g. John go store). Such «offline» measures require a patient to hold a sentence in working memory until they can make a metalinguistic judgment of its acceptability. This process relies on a notoriously fragile memory system in AD. Thus, one strong position is that «postinterpretive» working memory deficits underlie difficulties with offline measures of grammatical ability in AD (as sited in Reilly, Troche \& Grossman, 2011).

$\mathrm{AD}$ has two subtypes depending on its onset: early-onset (65 years of age or younger) or late-onset (over age 65) (Soukup, 1996; Swain, 2001; Ikejima et al., 2009; Zhu et al., 2015). However, late-onset is more common (Soukup, 1996). It has been shown that there is a correlation between the age of onset of clinical symptoms and the severity of the disease; hence, older patients tend to have a slower disease progression and less severe pathology at death (Mamede-Rosa, 2008). Symptoms are often gradual, irreversible, and significant enough to affect daily functioning (Masrani, 2018).

The identification of mutations in three genes that cause earlyonset $\mathrm{AD}(\mathrm{EAD})$ has already had a major impact on the understanding of the pathogenesis of AD. The evidence to date is largely consistent, suggesting a combination of environmental and genetic risk factors increase susceptibility to late-onset AD (LAD) (Hollingworth \& Williams, 2011). EAD is often associated with atypical symptoms including language and visuospatial dysfunction. Late-onset patients, by contrast, are significantly more impaired solely in the memory domain (Multani et al., 2016; Joupert et al., 2016). Due to this, there are some differences between the two subtypes. A crucial difference between early and late onset patients was language dysfunction. Early onset was associated with more language deficits. Early onset patients had more cases of aphasia (the loss or impairment of ability to use or understand speech) than the late onset patients (Kensinger, 1996). However, the language features of LAD patients can be similar to the people with normal aging.

The aim of the present study is to investigate if the use of coordinated and compound sentence structures of patients with LAD differs compared with a healthy controls of similar ages and also by direct comparison within the language tests. 


\section{Method}

\section{Participants}

A power analysis was performed before the implementation of the tests and it was revealed that this study could be done with the number of 39 patients with LAD. They have mild or moderate AD. The subject group was from Dokuz Eylul University, Faculty of Medicine, Department of Neurology. The ages of all the groups were similar (LAD: 78.5 / CG: 62.88) as well as their education.

\section{Language Tests}

Four different language tests were used in order to reveal the coordinated and compound sentence production of the participants: Picnic Picture Description Test (from Western Aphasia Battery, Revised: Kertesz, 2007), Cookie Theft Picture Description Test (from Boston Diagnostic Examination of Aphasia: Kaplan, Goodglass \& Weintraub, 2001), Story Picture Sequencing Test and Random Speech Test.

\section{Data Collection}

All participants were interviewed for approximately 10 minutes each with four tests and all interviews were recorded with a tape recorder and transcribed based on the DuBois' Discourse Transcription Symbols (1993). Just grammatically acceptable sentences were analysed (grammatically unacceptable sentences: Subject Group 6.81\% / Control Group $8.11 \%$ ) by using some statistical tests such as Qui-square, U Mann - Whitney and t test.

\section{Results}

Demographic and clinical variables in both groups were compared in order to reveal if all participants were suitable for the comparisons and it was found out that there was no statistically difference between LAD and control group (CG) (Age p: 0.150 / Education p: 0.223 / Gender p: 0.126).

\section{Sentence Length}

In order find the sentence length of LAD and CG, the number of sentences that these groups produced in four language tests. 
The number of words and sentences that the participants produced were calculated first and it revealed the sentence length of them in four different language tests.

Table 1. Number of the sentences produced by LAD and CG

\begin{tabular}{cccccc}
\hline Language Tests & N & Group & $\begin{array}{c}\text { Number of } \\
\text { Sentences }\end{array}$ & Mean (\%) & p \\
\hline \multirow{2}{*}{ Picnic Picture } & 26 & CG & 265 & 39.6 & 0,000 \\
\multirow{2}{*}{ Cookie Theft } & 39 & LOAD & 543 & 60.6 & \\
& 26 & CG & 230 & 29.1 & 0,000 \\
\multirow{2}{*}{ Story Picture Sequencing } & 39 & LOAD & 383 & 48.5 & \\
\multirow{2}{*}{ Random Speech } & 26 & CG & 293 & 30.9 & 0.000 \\
& 39 & LOAD & 441 & 46.5 & \\
& 26 & CG & 245 & 30.9 & 0,000 \\
\hline
\end{tabular}

Tha data in table 1 shows that there is a statistically difference between LAD and CG about the number of sentences. LAD patients produced more sentences in all language tests. The amount of speech of LAD patients is larger in picnic picture description test compared to the other tests.

Table 2. Sentence Length of LAD and CG

\begin{tabular}{cccccc}
\hline Language Tests & N & Group & Mean & $\begin{array}{c}\text { Standart } \\
\text { Deviation }\end{array}$ & p \\
\hline \multirow{2}{*}{ Picnic Picture } & 26 & CG & 6.484 & 1.909 & 0,000 \\
& 39 & LOAD & 4.768 & 1.230 & \\
Cookie Theft & 26 & CG & 8.529 & 3.515 & 0,000 \\
& 39 & LOAD & 5.473 & 1.620 & \\
Story Picture Sequencing & 26 & CG & 8.417 & 2.760 & 0,000 \\
\multirow{2}{*}{ Random Speech } & 39 & LOAD & 5.222 & 1.526 & \\
& 26 & CG & 8.550 & 3.505 & 0,000 \\
\hline
\end{tabular}

As seen in table 2, there is a statistically significant difference between LAD and CG about sentence length. LAD patients used shorter sentences in their speech compared to the CG. According to the averages, both groups used longer sentences only in random speech test. 
Мовні зміни в особистостей з хворобою Альигеймера пізнього...

\section{Comparisons of Coordinated and Compound Sentence Structures}

The data about the coordinated and compound sentence structures were analysed secondly.

Table 3. Comparisons of coordinated and compound sentence structures

\begin{tabular}{ccccccc}
\hline Language Tests & N & Group & $\begin{array}{c}\text { Coordinated } \\
\mathbf{f}(\%)\end{array}$ & $\mathbf{p}$ & $\begin{array}{c}\text { Compound } \\
\mathbf{f}(\%)\end{array}$ & $\mathbf{p}$ \\
\hline \multirow{2}{*}{ Picnic Picture } & 26 & CG & 76.9 & 0.134 & 38.5 & 0.836 \\
& 39 & LOAD & 59 & & 41 & \\
Cookie Theft & 26 & CG & 73.1 & 0.448 & 57.7 & 0.041 \\
& 39 & LOAD & 64.1 & & 33.3 & \\
Story Picture & 26 & CG & 84.6 & 0.107 & 46.2 & \multirow{2}{*}{ Sequencing } \\
Se.839 & 39 & LOAD & 66.7 & & 43.6 & \\
Random Speech & 26 & CG & 76.9 & 0.497 & 53.8 & 0.222 \\
\hline
\end{tabular}

According to the results in table 3 , there is a statistically significant difference between LAD and CG about compound sentences in cookie theft description test. It means that only in this test LAD produced less complex sentences (coordinated\&compound sentences) compared to the CG. However, in the other language tests, LAD patients used similar amount of coordinated and compound sentences.

Table 4. Comparisons of coordinated and compound sentences within tests

\begin{tabular}{cccccccc}
\hline & Groups & N & $\begin{array}{c}\text { Picnic } \\
\text { Picture } \\
\text { f (\%) }\end{array}$ & $\begin{array}{c}\text { Cookie } \\
\text { Theft } \\
\text { f (\%) }\end{array}$ & $\begin{array}{c}\text { Story Picture } \\
\text { Sequencing } \\
\text { f (\%) }\end{array}$ & $\begin{array}{c}\text { Random } \\
\text { Speech } \\
\text { f (\%) }\end{array}$ & p \\
\hline Coordinated & CG & 26 & 32 & 20.4 & 22.8 & 24.8 & 0.000 \\
Sentences & LAD & 39 & 23 & 23 & 23.9 & 30.1 & \\
Compound & CG & 26 & 20.2 & 27.3 & 26.3 & 26.3 & 0.000 \\
Sentences & LAD & 39 & 25 & 19.6 & 34.8 & 20.7 & \\
\hline
\end{tabular}

Table 4 reveals that there is a statistically significant difference about the use of coordinated and compound sentence structures. The use of coordinated and compound sentence structures vary in related with the tests.

In this study, coordinated and compound sentence structures were also analysed in terms of nominal and verbal predicates. 
Language Changes in Late-Onset Alzheimer's Disease

Table 5. Comparisons of coordinated and compound sentences with nominal predicates

\begin{tabular}{|c|c|c|c|c|c|c|}
\hline & Groups & $\mathbf{N}$ & $\begin{array}{c}\text { Picnic } \\
\text { Picture } \\
\text { f (\%) }\end{array}$ & $\begin{array}{c}\text { Cookie } \\
\text { Theft } \\
\text { f (\%) }\end{array}$ & $\begin{array}{l}\text { Story Picture } \\
\text { Sequencing } \\
\text { f (\%) }\end{array}$ & $\begin{array}{c}\text { Random } \\
\text { Speech } \\
\text { f (\%) }\end{array}$ \\
\hline $\begin{array}{l}\text { Nominal } \\
\text { Coordinated }\end{array}$ & $\mathrm{CG}$ & 26 & 26.9 & 19.2 & 19.2 & 19.2 \\
\hline Sentences & LAD & 39 & $\begin{array}{c}2.6 \\
\mathrm{p}=0.003\end{array}$ & $\begin{array}{c}7.7 \\
p=0.293\end{array}$ & $\begin{array}{c}2.6 \\
\mathrm{p}=0.023\end{array}$ & $\begin{array}{c}8.7 \\
\mathrm{p}=0.174\end{array}$ \\
\hline $\begin{array}{l}\text { Nominal } \\
\text { Compound }\end{array}$ & $\mathrm{CG}$ & 26 & 26.9 & 23.1 & 11.5 & 23.1 \\
\hline Sentences & LAD & 39 & $\begin{array}{c}5.1 \\
\mathrm{p}=0.013\end{array}$ & $\begin{array}{c}2.6 \\
\mathrm{p}=0.009\end{array}$ & $\begin{array}{c}7.7 \\
p=0.600\end{array}$ & $\begin{array}{c}2.6 \\
\mathrm{p}=0.009\end{array}$ \\
\hline
\end{tabular}

Table 5 shows that within nominal coordinated sentences, there is a statistically significant difference between $\mathrm{LAD}$ and $\mathrm{CG}$ in picnic picture description test and also in story picture sequencing test. However, within nominal compound sentences, there is a statistically significant difference between LAD and CG in all tests except for picnic picture test.

Table 6. Comparisons of coordinated and compound sentences with verbal predicates

\begin{tabular}{|c|c|c|c|c|c|c|}
\hline & Groups & $\mathbf{N}$ & $\begin{array}{c}\text { Picnic } \\
\text { Picture } \\
\text { f (\%) }\end{array}$ & $\begin{array}{c}\text { Cookie } \\
\text { Theft } \\
\text { f (\%) }\end{array}$ & $\begin{array}{l}\text { Story Picture } \\
\text { Sequencing } \\
\text { f }(\%)\end{array}$ & $\begin{array}{c}\text { Random } \\
\text { Speech } \\
\text { f }(\%)\end{array}$ \\
\hline $\begin{array}{c}\text { Verbal } \\
\text { Coordinated }\end{array}$ & $\mathrm{CG}$ & 26 & 76.9 & 65.4 & 80.8 & 69.2 \\
\hline Sentences & LAD & 39 & $\begin{array}{c}59 \\
\mathrm{p}=0.134\end{array}$ & $\begin{array}{c}64.1 \\
p=0.916\end{array}$ & $\begin{array}{c}66.7 \\
p=0.213\end{array}$ & $\begin{array}{c}69.2 \\
p=1.000\end{array}$ \\
\hline $\begin{array}{c}\text { Verbal } \\
\text { Compound }\end{array}$ & $\mathrm{CG}$ & 26 & 23.1 & 50 & 42.3 & 42.3 \\
\hline Sentences & LAD & 39 & $\begin{array}{c}41 \\
\mathrm{p}=0.134\end{array}$ & $\begin{array}{c}33.3 \\
p=0.179\end{array}$ & $\begin{array}{c}41 \\
\mathrm{p}=0.918\end{array}$ & $\begin{array}{c}35.9 \\
\mathrm{p}=0.603\end{array}$ \\
\hline
\end{tabular}

As seen in table 6, there is no statistically significant difference between $\mathrm{LAD}$ and $\mathrm{CG}$ about coordinated and compound sentences with verbal predicates. It means that LAD patients use similar amount of coordinated and compound sentences with verbal predicates in their speech. 


\section{Discussion and Conclusion}

The present study investigated the language changes of late-onset Alzheimer's disease in terms of syntactic analysis. In the first step, the number of sentences used by LAD patients were analysed and it was revealed that the speech amount of these patients was larger compared to the people with normal aging in all four language tests. LAD patients produced more sentences in picnic picture description test and less sentences in random speech test. In contrast, people with normal aging produced less sentences in cookie theft picture description test. When LAD patients describe any picture or answer a question, they produce sentences that do not require much processing, such as Subject-ObjectVerb, rather than clauses that contain more than one word. This type of sentences is not sufficient to answer the whole picture or to answer the question fully. Therefore, the total number of sentences of LAD patients is higher than that of normal individuals.

The second finding is related with the sentence length of LAD patients. It was revealed that the sentence length of LAD patients was different from the control group. Although LAD patients used more sentences, the sentences were shorter than the control group. LAD patients described the pictures with shorter sentences (with less words). However, people with normal aging described the pictures in details using longer sentences with conjunctions etc. Considering the language tests, the sentence length of LAD patients was bigger in cookie theft picture description test and smaller in picnic picture description test. Overall, their general performance about the speech amount was poor. There are similar findings in literature about the speech amount of $\mathrm{AD}$ patients. It is believed that this poor performance is due to brain atrophy. It is suggested that picture naming is a task predominantly dependent on temporal or posterior brain areas, whereas verbal fluency is more dependent on frontal or frontalsubcortical brain areas. Even though patients with $\mathrm{AD}$ have no frontal brain atrophy, they do experience difficulty in naming and fluency tasks involving verbs (Beber, Cruz \& Chaves, 2015).

The third finding is about the use of coordinated and compound sentence structures. According to the results, LAD patients used similar number of coordinated and compound sentences compared to their aged matched peers. However, only in cookie theft picture test, the 
number of compound sentences was different compared to the control group. They produced less compound sentences in this test. Cookie theft picture description test is a more complex test than the others. When it is considered that these patients have visual problems in terms of their age, it is a situation that we are expecting to see this picture and hence they will have difficulty in producing sentences. It is known that $\mathrm{AD}$ patients have working memory problems due to the deficits in neural interconnections between the posterior and frontal brain areas (Altmann \& McClung, 2008). Working memory is a cognitive system that is related to sentence processing and provides linguistic information for this process (Sung, Kyung \& Hyang, 2013). These problems related with the working memory can also cause difficulties in sentence comprehension and sentence production (Altmann \& McClung, 2008). Some studies related to sentence processing indicate a left-temporal network for syntactic processing and bilateral tempro-frontal networks for semantic processing (Lukic et al., 2013).

The findings about the coordinated and compound sentences with nominal and verbal predicates showed that LAD patients use similar number of nominal and verbal complex sentences compared to the control group. Within nominal coordinated sentences, the difference between LAD and CG is significant just in picnic picture description test and in story picture sequencing test. However, within nominal compound sentences, there is a statistically significant difference between LAD and CG in all tests except for picnic picture test. From previous studies, it is known that LAD patients tend to use more nominal sentences (Can \& Kuruoglu, 2017; Can et al., 2018; Can \& Kuruoglu, 2018). However, these sentences were basic sentences. In coordinated and compound sentence structures, LAD patients preferred more verbal sentences. In literature, there are similar findings parallel to our study. In these studies, it was revealed that AD patients used less complex sentence structures compared to the control group (Hier et al., 1985; Croisile et al., 1996; Waters \& Caplan, 1997, 1999, 2001).

The effect of $\mathrm{AD}$ on syntax is controversial. Some researchers have reported syntactic impairments in $\mathrm{AD}$, while others claim that any apparent deficits are in fact due to difficulties with memory and semantics (Reilly, Troche \& Grossman, 2011). The former ones say that the stages of $\mathrm{AD}$ are determinant of the language impairment in $\mathrm{AD}$ and the impairment is just observed in the complex sentence structures 
(Caramelli, Mansur \& Nitrini, 1998; Emery, 2000; Boschi, 2017). AD patients use the same syntactic structures and the same morphological forms as their cognitively intact participants, and make very few structural errors (Kave \& Dassa, 2018). However, the performance of $\mathrm{AD}$ patients becomes worse when the complex sentence structures occur more frequently (Caplan \& Waters, 1999). There is reduction in at least one aspect of syntactic complexity (e.g., simpler sentences or more syntactic errors) (Ahmed et al., 2012).

Patients with AD presented more word-finding difficulties, revisions and repetitions, and the syntactic index was lower than controls (Lira et al., 2011). Croisile et al. (1996) documented a reduction in the use of subordinate clauses in $\mathrm{AD}$, but no di'erence in grammatical errors between patients and controls. Kavé and Levy (2003) found that persons with AD used the same syntactic structures and the same morphological forms as did cognitively intact participants, and made very few structural errors. Nevertheless, other studies have noted that $\mathrm{AD}$ leads to grammatical di'culties as well. For example, Ahmed, de Jager, Haigh, and Garrard (2012) reported that a third of their participants with $\mathrm{AD}$ demonstrated reduction in at least one aspect of syntactic complexity (e.g., simpler sentences or more syntactic errors). Kemper et al. (2001) showed that AD accelerates age-related deterioration in both propositional content and grammatical complexity.

Language may be partitioned into two broad categories: production and comprehension. Early AD patients are essentially impaired on word production while comprehension is typically affected at more advanced stages of the disease. Patients are especially sensitive to the lexical properties of words: selection of items to be tested should take into consideration word characteristics, such as frequency of usage, regularity in the spelling-to-sound correspondence and age of acquisition. For example, in picture naming tasks, patients generally perform better with more frequent words and those acquired earlier in childhood. The assessment of single word production and comprehension should include both verbal and written words. Spelling errors are often observed in early $\mathrm{AD}$; spelling may be assessed orally or with a dictation that includes both regular (red) and irregular (blood) words, with varying frequency of usage. However, not all aspects of language are impaired in $\mathrm{AD}$; phonological processing and syntax are generally preserved, at least in the early stage (Rainville et al., 2007). 
In the moderate stage, the syntactic complexity of $\mathrm{AD}$ patients' speech output diminishes. Speech may become paragrammatic (e.g. improper use of syntactic structures or function words). AD patients also have increased problems with the comprehension of syntactically complex sentences. For example, patients show difficulties in processing reversible or passive sentences (e.g. John loves Mary and Mary is loved by John). This ability to process sentences using syntactic information, however, only appears to be lost in the moderate to severe stage of the disease (Joupert et al., 2007).

Neuroimaging and lesion studies have long implicated inferior frontal lobe structures in grammatical processing. Grammatical deficits have been reported in both $\mathrm{AD}$ and the non-fluent variant of primary progressive aphasia (Reilly, Troche \& Grossmann, 2011). Due to these problems, the participants in our study had also poor perfomance on grammatical processing.

In sum, the current study shows that the language use of LAD patients is similar to the people with normal aging. Grammatical complexity has a relation with cognitive system as well as working memory. It is clear that there is no tendency to use coordinated and compound sentences in the speech of LAD patients because increased grammar complexity activates prefrontal cortex and this area is damaged in $\mathrm{AD}$ patients. However, when other sentence structures in $\mathrm{AD}$ patients are examined, different findings related with syntactic abilities of LAD patients could be revealed.

\section{References}

Atkins, C. (2008). The Alzheimer's Answer Book: Professional Answers to More Than 250 Questions about Alzheimer's and Dementia. Illinois: Sourcebooks.

Ahmed, S., de Jager, C.A., Haigh, A.M.F., \& Garrard, P. (2012). Logopenic aphasia in Alzheimer's disease: clinical variant or clinical feature? Journal of Neurology, Neurosurgery, and Psychiatry, 83(11), 1056-1062. https://doi.org/10.1136/jnnp2012-302798

Altmann, L.J., \& McClung, J.S. (2008). Effects of semantic impairment on language use in Alzheimer's disease. In Seminars in speech and language, 29(1), 18-31. https://doi.org/10.1055/s-2008-1061622

Bates, E., Harris, C., Marchman, V., Wulfeck, B., \& Kritchevsky, M. (1995). Production of complex syntax in normal ageing and Alzheimer's disease. Language and Cognitive Processes, 10(5), 487-539. https://doi.org/10.1080/01690969508407113

Bayles, K., Kazniak, A., \& Tomoeda, C.K. (1987). Communication and cognition in normal aging and dementia. Boston: Little Brown. 
Beber, B.C., Cruz, A.N., \& Chaves, M.L. (2015). A behavioral study of the nature of verb production deficits in Alzheimer's disease. Brain and Language, 149, 128134. https://doi.org/10.1016/j.bandl.2015.07.010

Boschi, V., Catricala, E., Consonni, M., Chesi, C., Moro, A., \& Cappa, S.F. (2017). Connected speech in neurodegenerative language disorders: A review. Frontiers in Psychology, 8(269), 1-21. https://doi.org/10.3389/fpsyg.2017.00269

Budson, A.E. (2011). Memory Dysfunction in Dementia (Vol. 7), The handbook of Alzheimer's disease and other dementias. In A.E. Budson \& N.W. Kowall (Eds.). John Wiley, Sons. https://doi.org/10.1002/9781444344110.ch11

Camicioli, R. (2007). Differentiation from non-Alzheimer dementia. Clinical Diagnosis and Management of Alzheimer's Disease. Editor Serge Gauthier. UK: Informa.

Can, E., \& Kuruoglu, G. (2017). Sentence Length of Turkish Patients with Early and Late-Onset Alzheimer's Disease. Humanities and Social Sciences Review, 6(02), 69-78.

Can, E., \& Kuruoglu, G. (2018). A comparison of Sentence Production of Turkish Patients with Early and Late-Onset Alzheimer's Disease. International Journal of Psycho-Educational Sciences, 7(1), 74-85.

Can, E., Kuruoglu, G., \& Ozsoy, A.S. (2018). Geç başlangıçlı Alzheimer tipi demans hastalarının dil kullanımı: Basit tümce açısından inceleme. In Neslihan Kansu Yetkiner \& Mehmet Şahin (Eds.), Dilbilim ve Çevribilim Yazıları, (pp. 36-47). Ankara: Anı Yayıncılık.

Caplan, D., \& Waters, G.S. (1999). Verbal working memory and sentence comprehension. Behavioral and Brain Sciences, 22(01), 77-94. https://doi. org/10.1017/S0140525X99001788

Caramelli, P., Mansur, L.L., \& Nitrini, R. (1998). Language and communication disorders in dementia of the Alzheimer type. In Harry A. Whitaker \& Brigitte Stemme (Eds.), Handbook of Neurolinguistics, (pp. 463-473). USA : Academic Press.

Croisile, B., Ska, B., Brabant, M.J., Duchene, A., Lepage, Y., Aimard, G., \& Trillet, M. (1996). Comparative study of oral and written picture description in patients with Alzheimer's disease. Brain Language, 53, 1-19. https://doi. org/10.1006/brln.1996.0033

Cummings, J.L. (2007). Alzheimer Hastalı̆̆ ve İlişkili Demansların Nöropsikiyatrik Özellikleri. Çev. Doç. Dr. Gökhan Erkol ve Dr. Barış Metin. İngiltere: Taylor Francis.

Davidson, T., \& Villiers, J.D. (2011). Language Impairment. The Gale Encyclopedia of Children's Health: Infancy Through Adolescence. In Jacqueline L. Longe (Ed.). Detroit : Gale Cengage Learning.

Du Bois, J.W., Schuetze-Coburn, S., Cumming, S., \& Paolino, D. (1993). Outline of discourse transcription. In Jane A. Edwards \& Martin D. Lampert (Eds.), Talking Data: Transcription and coding in discourse research, (pp. 45-89). New York: Psychology Press.

Emery, V.O. (2000). Language impairment in dementia of the Alzheimer type: A hierarchical decline? International Journal of Psychiatry in Medicine, 30, 145-164. https://doi.org/10.2190/X09P-N7AU-UCHA-VW08

Ferris, S.H., \& Farlow, M. (2013). Language impairment in Alzheimer's disease and benefits of acetylcholinesterase inhibitors. Clinical interventions in aging, 8, 1007-1014. https://doi.org/10.2147/CIA.S39959 
Franz, J.F. (2001). Alzheimer's Disease. Gale Encyclopedia of Nursing and Allied Health. In Kristine M. Krapp (Ed.). Detroit : Thomson Gale.

Fraser, K.C., Meltzer, J.A., \& Rudzicz, F. (2016). Linguistic features identify Alzheimer's disease in narrative speech. Journal of Alzheimer's Disease, 49(2), 407-422. https://doi.org/10.3233/JAD-150520

Glosser, G., Friedman, R., Kohn, S., Sands, L., \& Grugan, P. (1998). Cognitive mechanisms for processing nonwords: Evidence from Alzheimer's disease. Brain and Language, 63, 32-49. https://doi.org/10.1006/brln.1997.1924

Gourle, M.M. (2001). Occupational therapy. Gale Encyclopedia of Nursing and Allied Health. In Kristine M. Krapp (Ed.). Detroit: Thomson Gale.

Guha, M. (2012) The Gale Encyclopedia of Children's Health: Infancy through Adolescence (2nd ed.), Reference Reviews. Vol. 26. Issue: 3, pp. 35-37, https:// doi.org/10.1108/09504121211211398

Hier, D.B., Hagenlocker, K., \& Shindler, A.G. (1985). Language disintegration in dementia: effects of etiology and severity. Brain Language, 25, 117-133. https:// doi.org/10.1016/0093-934X(85)90124-5

Hollingworth, P., \& Williams, J. (2011). Genetic Risk Factors for Dementia. In A.E. Budson \& N.W. Kowall (Eds.), The handbook of Alzheimer's disease and other dementias (Vol. 7). John Wiley \& Sons. https://doi. org/10.1002/9781444344110.ch6

Ikejima, C., Yasuno, F., Mizukami K., et al. (2009). Prevalence and causes of earlyonset dementia in Japan: a population-based study. Stroke, 40, 2709-2727. https:// doi.org/10.1161/STROKEAHA.108.542308

Joubert, S., Joncas, S., Barbeau, E., Joannette, Y., \& Ska, B. (2007). Cognition. In S. Gauthier (Ed.), Clinical diagnosis and management of Alzheimer's disease (3rd ed.), (pp. 165-176). Martin Dunitz \& Parthenon publishing.

Joubert, S., Gour, N., Guedj, E., Didic, M., Guériot, C., Koric, L., Ranjeva, J., Felician, O., Guye, M., \& Ceccaldi, M. (2016). Early-onset and late-onset Alzheimer's disease are associated with distinct patterns of memory impairment. Cortex, 74, 217-232. https://doi.org/10.1016/j.cortex.2015.10.014.

Kaplan, E., Goodglass, H., \& Weintraub, S. (2001). Boston naming test (2nd ed.). Philadelphia, PA: Lippincott Williams \& Wilkins.

Kavé, G., \& Levy, Y. (2003). Morphology in picture descriptions provided by persons with Alzheimer's disease. Journal of Speech, Language, and Hearing Research, 46, 341-352. https://doi.org/10.1044/1092-4388(2003/027)

Kavé, G., \& Dassa, A. (2018). Severity of Alzheimer's disease and language features in picture descriptions. Aphasiology, 32(1), 27-40. https://doi.org/10.1080/026870 38.2017.1303441

Kemper, S., LaBarge, E., Ferraro, R., Cheung, H., \& Storandt, M. (1993). On the preservation of syntax in Alzheimer's disease. Archives of Neurology, 50, 81-86. https://doi.org/10.1001/archneur.1993.00540010075021

Kemper, S., Thompson, M., \& Marquis, J. (2001). Longitudinal change in language production: E'ects of aging and dementia on grammatical complexity and propositional content. Psychology and Aging, 16, 600-614. https://doi. org/10.1037/0882-7974.16.4.600

Kensinger, E. (1996). Early and Late Onset as Subdivisions of Alzheimer's Disease. Harvard Brain, (pp. 26-36).

Kertesz, A. (2007). Western Aphasia Battery (Revised) PsychCorp. San Antonio. 
Мовні зміни в особистостей з хворобою Альцгеймера пізнього...

Lira, J.O., Ortiz, K.Z., Campanha, A.C., Bertolucci, P.H.F., \& Minett, T.S.C. (2011). Microlinguistic aspects of the oral narrative in patients with Alzheimer's disease. International Psychogeriatrics, 23(3), 404-412. https://doi.org/10.1017/ S1041610210001092

Lu, L.C., \& Bludau, J.H. (2011). Alzheimer's Disease (Biographies of Disease). California: Greenwood.

Lukic, S., Bonakdarpour, B., Den Ouden, D., Price, C., \& Thompson, C. (2013). Neural Mechanisms of Verb and Sentence Production: A Lesion-deficit Study. Procedia-Social and Behavioral Sciences, 94, 34-35. https://doi.org/10.1016/j. sbspro.2013.09.014

Mamede-Rosa, M.L. (2008). Alzheimer's Disease. Alzheimer's Disease Research Trends. In A.P. Chan (Ed.). New York: Nova Science Publishers.

Mandell, A.M., \& Green, R.C. (2011). Alzheimer's Disease. In A.E. Budson \& N.W. Kowall (Eds.), The handbook of Alzheimer's disease and other dementias (Vol. 7). John Wiley \& Sons. https://doi.org/10.1002/9781444344110.ch1

Masrani, V. (2018). Detecting dementia from written and spoken language (T). University of British Columbia. Retrieved from https://open.library.ubc.ca/ collections/ubctheses/24/items/1.0362923.

Multani, N., Rudzicz, F., \& Tartaglia, M.C. (2016). Comparing Neuropsychiatric and Language Features in Early-onset and Late-onset Alzheimer's Disease. Alzheimer's \& Dementia: The Journal of the Alzheimer's Association, 12(7), 490. https://doi.org/10.1016/j.jalz.2016.06.968

Rainville, C., Caza, N., Belleville, S., \& Gilbert, B. (2007). Neuropsychological assessment. In S. Gauthier (Ed.), Clinical Diagnosis and Management of Alzheimer's Disease (3rd.). Oxon : Informa Healthcare.

Reilly, J., Troche, J., \& Grossman, M. (2011). Language Processing in Dementia. In A.E. Budson \& N.W. Kowall (Eds.), The handbook of Alzheimer's disease and other dementias (Vol. 7). John Wiley \& Sons. https://doi. org/10.1002/9781444344110.ch12

Soukup, J.E. (1996). Alzheimer's Disease: A Guide to Diagnosis, Treatment, and Management. USA : Praeger Publishers.

Sunderman, M. (2012). The Effects of Alzheimer's Disease on Expressive Language Over Time. (Unpublished doctoral dissertation). Columbus, $\mathrm{OH}:$ Ohio State University.

Sung, J.E., Kyung, K.J., \& Hyang, J.J. (2013). Working Memory Capacity and its Relation to Passive Sentence Comprehension in Persons with Mild Cognitive Impairment. In Clinical Aphasiology Conference : Clinical Aphasiology Conference.

Swain, L. (2001). Aging and the aged. Gale Encyclopedia of Nursing and Allied Health. Editors Kristine M. Krapp. Detroit : Thomson Gale.

Swartout-Corbei, D.M. (2001). Dementia. Gale Encyclopedia of Nursing and Allied Health. Editors Kristine M. Krapp. Detroit : Thomson Gale.

Thomas, P., \& Hazif-Thomas, C. (2016). Language Disorders in Alzheimer's Disease and Phatic Function. Open Journal of Psychiatry, 6, 213-217. http://dx.doi. org/10.4236/ojpsych.2016.63026

Waters, G.S., \& Caplan, D. (1997). Working memory and on-line sentence comprehension in patients with Alzheimer's disease. Journal of Psycholinguistic Research, 26(4), 377-400. https://doi.org/10.1023/A:1025073902269

Waters, G.S., \& Caplan, D. (1999). Verbal working memory capacity and on-line sentence processing efficiency in the elderly. In S. Kemper \& R. Kliegl (Eds.), 
Constraints on language: Aging, grammar and memory, (pp. 107-136). Boston, MA: Kluwer.

Waters, G.S., \& Caplan, D. (2001). Age, working memory and on-line syntactic processing in sentence comprehension. Psychology and Aging, 16, 128-144. https://doi.org/10.1037/0882-7974.16.1.128

Zhu, X.C, Tan, L, Wang, H.F. et al. (2015). Rate of early onset Alzheimer's disease: a systematic review and meta-analysis. Ann. Transl. Med, 3, 38-43.

Zimmerer, V.C., Wibrow, M., \& Varley, R.A. (2016). Formulaic language in people with probable Alzheimer's disease: a frequency-based approach. Journal of Alzheimer's Disease, 53(3), 1145-1160. https://doi.org/10.3233/JAD-160099

\begin{abstract}
АНОТАЦІЯ
Хвороба Альцгеймера (ХА) є найбільш частою причиною втрати когнітивних функцій і деменції у літніх людей. Порушення мовлення з'являються на ранніх стадіях ХА і є важливим показником діагнозу, хоча зазвичай вони обтяжуються порушенням пам'яті і виконавчих функцій. Відомо, що при ХА порушення мовлення відбувається непропорційно: семантичні та прагматичні мовні системи більш схильні до порушень, ніж синтаксис. Проте, синтаксис також може бути порушеним на середній і важкій стадіях ХА. Особливості мовлення можуть бути різними в залежності від початку хвороби Альцгеймера. Вона (ХА) класифікується на два підтипи: ранній початок (до 65 років) і пізній початок (після 65 років). Пізній початок є найбільш поширеною формою ХА. Відтак, мета цього дослідження - виявити мовленнєві зміни у 39 пацієнтів 3 пізнім початком Хвороба Альцгеймера і порівняти їх з контрольною групою. Контрольна група була обрана з респондентів старших 65-річного віку, з рівнем освіти, як і в групи досліджуваних пізнього початку ХА, без серйозного неврологічного і психічного захворювання. Мовлення хворих було записане у вигляді транскрипції з використанням символів транскрипції Du Bois. Результати показали, що, хоча кількість речень у пачієнтів з ПХА було більще, проте ці речення були короткими й складалися з малої кількості слів, тобто «кількість мовлення» була меншою, ніж у контрольній групі. Пацієнти з ПБА в основному відтворювали більше речень в тесті на опис картинки «Пікнік» $i$ менше речень у спонтанному мовленні. Крім того, довжина речень пацієнтів з ПБА була більще в тесті на опис картинки "Крадіжки печива» і менше в тесті на опис картинки «Пікнік». Проте, загальна продуктивність «кількості мовлення» була поганою. У дослідженні були отримані так само результати по відтворенню узгоджених і складних речень. Було виявлено, що пачієнти з ПХА використовували близьку з контрольною групою кількість узгоджених $i$ складних речень. У висновку зазначено, що синтаксичні особливості мовлення пацієнтів з ПХА не сильно відрізняються від мовлення здорових людей тієї ж вікової групи.
\end{abstract}

Ключові слова: хвороба Альцгеймера, хвороба Альцгеймера з пізнім початком, узгоджені речення, складні речення, довжина речення. 
Мовні зміни в особистостей з хворобою Альцсгеймера пізнього...

Кан Эда, Куруоглу Гульмира. Языковые изменения у больных Альцгеймером при позднем начале болезни

\section{АННОТАЦИЯ}

Болезнь Альцгеймера (БА) является наиболее частой причиной утраты когнитивных функций и деменции у пожилых людей. Нарушения речи появляются на ранних стадиях БА и являются важным показателем диагноза, хотя обычно они отягощаются нарушением памяти и исполнительных функций. Известно, что при БА нарушение речи прооисходит непропорционально: семантические и прагматические языковые системы более подвержены нарушениям, чем синтаксис. Тем не менее, синтаксические признаки также могут быть нарушены в средней и тяжелой стадиях БА. Особенности языка могут быть различными в зависимости от начала болезни. БА классифицируется на два подтипа: раннее начало (до 65 лет) и позднее начало (старше 65 лет). Позднее начало является наиболее распространенной формой БА, и цель этого исследования - выявить языковые изменения у 39 пациентов с поздним началом Болезнь Альцгеймера (ПБА) и сравнить их с контрольной группой. Контрольная группа была выбрана из респондентов, соответствующего возраста и уровня образования как и группы ПБА, без серьезного неврологического и психического заболевания. Данные речи больных были записаны в виде транскрипции с использованием символов транскрипции Du Bois. Результаты показали, что, хотя количество предложений у пациентов с ПБА было больще, но эти предложения были краткими и состояли из малого количества слов, то есть «количество речи» было меньше, чем в контрольной группе. Пациенты с ПБА в основном воспроизводили больше предложений в тесте описания картинки «Пикник» и меньше предложений в тесте на спонтанную речь. Кроме того, длина предложения пациентов с ПБА была больще в тесте описания картинки "Кражи печенья" и меньще в тесте описания картинки "Пикник». Тем не менее, общая производительность "количества речи» была плохой. В исследовании были получены так же результаты по воспроизведению согласованных и сложных предложениях. Было выявлено, что пациенты с ПБА использовали близкое с контрольной группой количество согласованных и сложных предложений. В заключении можем сказать, что синтаксические особенности речи пациентов с ПБА не сильно отличаются от речи здоровых людей той же возрастной группы.

Ключевые слова: болезнь Альцгеймера, болезнь Альцгеймера с поздним началом, согласованные предложения, сложные предложения, длина предложения. 